\title{
A "SeCreta fundaÇão" da Psiquiatria: CONSIDERAÇÕes SOBRE A ANÁLISE FOUCAULTIANA DA HISTÓRIA DA LOUCURA
}

\author{
Tereza Cristina B. Calomeni ${ }^{\star}$
}

“Os homens são tão necessariamente loucos que seria ser louco (outro tipo de loucura) não ser louco."

(PASCAL, 1973, p. 138).

\begin{abstract}
Resumo
O artigo que ora se apresenta reflete sobre $a$ História da loucura, texto que dá inicio às análises histórico-arqueológicas de Michel Foucault. A partir de um recorte temporal, que abrange o período compreendido entre a Renascença e a Modernidade, Foucault examina as distintas formas de percepção do louco até a instituição da loucura como doença mental. Uma "arqueologia do silêncio" à que se submete a loucura, não uma história da psquiatria, o texto foucaultiano indaga sobre as condições históricas que favorecem o surgimento da psiquiatria como discurso científico sobre a loucura e a instituição do asilo como lugar de tratamento do louco.

Palavras-chave: loucura; psquiatria; asilo.

\section{The "SeCret foundation" of Psychitatry: CONSIDERATIONS ON THE FOUCAULDIAN ANALYSIS OF THE HISTORY OF MADNESS}

\begin{abstract}
The article that is now presented reflects upon the History of madness, text that begins from Michel Foucault's historical-archaeological analyses. Starting from a temporal writing which includes the period comprised between the Renaissance and Modernity, Foucault scrutinizes the distinct forms of the social perception of the mad person up to the institution of madness as a mental disease. An "archaeology of silence" to which madness is submitted, not a history of psychiatry, Foucault's text questions about the historical conditions that favour the occurrence of psychiatry as a scientific discours about madness and the institution of the asylum as a place for the treatment of mad person.
\end{abstract}

Keywords: Madness. Psychiatry. Asylum.

^ Professora de Filosofia. Mestrado, Doutorado e Pós-Doutorado em Filosofia na Pontifícia Universidade Católica do Rio de Janeiro. Mestrado em Educação na Universidade Federal Fluminense. Professora de Filosofia (Categoria: Adjunto 4) da Universidade Federal Fluminense desde 1986. Endereço: Universidade Federal Fluminense, Instituto de Ciências Humanas e Filosofia / Departamento de Filosofia. Campus do Gragoatá - Rua Professor Marcos Waldemar de Freitas Reis, Blocos N e O. São Domingos - Niteroi, RJ - Brasil. CEP: 24210-201.

E-mail: terezacalomeni@uol.com.br 
Texto inaugural das análises histórico-arqueológicas de Michel Foucault, História da loucura na idade clássica (Histoire de la folie à l'âge classique) ${ }^{1}$ põe em cena um dos mais instigantes e controvertidos pensadores do século XX. Originalmente escrito como tese de doutorado, História da loucura, desde o momento de sua aparição, em 1961, é um texto provocativo e, por vezes, desconcertante. Não sem razão: com a leitura de suas primeiras páginas, pode-se pressentir que a intenção não é pronunciar um elogio à Psiquiatria ou à Psicanálise, mas, ao contrário, inscrevê-las no interior de uma discussão radical acerca da racionalidade ocidental, melhor, acerca do "poder do discurso racional" (FOUCAULT, 2006, p. 95) sobre a linguagem da loucura e o comportamento do louco.

Se em textos anteriores, como Doença mental e personalidade (Maladie mental et personnalité), publicado em 1954, ${ }^{2}$ a palavra de Foucault ainda não tem o peso e a força que adquire a partir de 1961, com a publicação de História da loucura, já se pode pressupor e avaliar o alcance e a repercussão das formulações aí forjadas e das críticas aí expostas. Renunciando ao "conforto das verdades terminais" (FOUCAULT apud ERIBON, 1990, p. 103), Foucault desconfia de alguns dos ideais mais caros à Psiquiatria e contesta alguns dos mitos sobre os quais se edifica a história do discurso psiquiátrico.

Em 1975, relembra o silêncio e a solidão a que foi subjugado e as "injúrias" que lhe foram endereçadas - sobretudo por psiquiatras marxistas (FOUCAULT, 2006, p. 67-100) - após a edição de seu primeiro grande livro e confessa que "tinha a impressão de ter acendido um estopim" (FOUCAULT, 2006, p. 75), impressão, aliás, bem apropriada a um pensador que se define como um "pirotécnico", interessado em escrever "pacotes de explosivos":

Eu encarava esse livro como uma espécie de vento verdadeiramente material, e continuo a sonhar com ele assim, uma espécie de vento que faz estourar as portas e as janelas... Meu sonho é que ele fosse um explosivo eficaz como uma bomba, e bonito como fogos de artifício. (FOUCAULT, 2006, p. 75).

Apesar das referências elogiosas de Canguilhem - presença marcante na vida filosófica de Foucault e um dos três integrantes da banca de avaliação e julgamento da tese $\mathrm{e}^{3}$ - de fato, História da loucura provoca um significativo malestar, um inegável desconforto. No entanto, entre 1961 e o momento de expressão do efeito bombástico e explosivo do livro, há, na opinião de Foucault, um tempo de singular e sugestivo silêncio:

Entre o momento em que comecei a colocar este tipo de problema em relação à psiquiatria e seus efeitos de poder e o momento em que tais questões começaram a encontrar um eco na sociedade, passaram-se anos. Eu tinha a impressão de ter acendido um estopim e, depois, não se ouvia nada. [...] eu desafinava o piano, esperando a detonação, e a detonação não vinha (FOUCAULT, 2006, p. 75). 
Se a intelectualidade marxista silencia, se psiquiatras e psicólogos se constrangem, "literatos", como Blanchot e Barthes (FOUCAULT, 2006, p. 76), manifestam-se francamente mais sensíveis ao que insinua Foucault com suas inusitadas questões sobre a loucura. Ainda que História da loucura não esteja estreitamente referido à literatura, mas à "materialidade" dos "espaços fechados", o campo literário acolhe, de imediato, o ousado e polêmico texto foucaultiano.

Inspirado em Nietzsche e em Bataille, Foucault deseja que a loucura apareça como a "parte maldita" da razão ocidental. Para tanto, se debruça sobre a poeira dos arquivos 4 e se aproxima da "infame" palavra dos loucos, estratégia que retoma, mais tarde, no período das investigações genealógicas sobre criminalidade e delinquência. Até neste ponto, a crítica de psiquiatras e, sobretudo, de historiadores, pretende ser meticulosa e corrosiva: aponta equívocos e imprecisões no trabalho de pesquisa e, mais que isto, acusa Foucault de fazer literatura - uma literatura irremediavelmente alheia à cruel realidade dos asilos; uma literatura sustentada por um material estranhamente ausente dos arquivos da história da Psiquiatria.

Não é pertinente ou justificada a acusação: a motivação para trabalhar com textos esquecidos, com arquivos empoeirados e deixados à margem, com um "material não 'nobre', [um material] 'plebeu'” (FOUCAULT, 1984b, p. 129) é inteiramente compreensível: História da loucura não é uma história da Psiquiatria; antes, é uma história do modo como a loucura é "percebida" em determinadas fases da cultura ocidental; uma história que interroga sobre o "grau zero da história da loucura, no qual ela é experiência indiferenciada, experiência ainda não partilhada da própria partilha" (FOUCAULT apud ERIBON, 1990, p. 103); uma história destinada a fazer emergir a "cena primitiva" da interdição da "vivacidade" da loucura.

Um dos traços da singularidade da "arqueologia" é justamente a distância que estabelece tanto da história convencional das ciências quanto da epistemologia, consideradas insuficientes à compreensão das condições históricas de possibilidade de surgimento, no século XIX, de um discurso teórico como a Psiquiatria. Não é bastante proceder como um historiador das ciências nem é adequado ao objeto em questão privilegiar as noções fundamentais da epistemologia - veracidade, cientificidade, superação, recorrência - à procura de um suposto progresso conceitual. Se Foucault é influenciado pela epistemologia, ${ }^{5}$ a "arqueologia" se distingue: como um "geólogo", Foucault avalia o terreno, escava o solo mais profundamente, investiga as camadas mais fundas para trazer à superfície o que não revela a epistemologia ou a história convencional. Importa verificar como se conforma o "obscuro" gesto de partilha entre razão e loucura. Deste ponto de vista, o que emerge da escavação realizada não poderia estar presente nos arquivos da história da Psiquiatria. Em História da loucura, ainda não é explícita a distinção entre ciência e saber - distinção presente em As palavras e as coisas (Les mots et les choses - 1966) e em textos posteriores - , mas todo o movimento de Foucault em direção ao esclarecimento da situação da loucura na Idade Moderna pressupõe o saber como condição de possibilidade da ciência. Não é gratuita a instituição, em História da loucura, de dois níveis básicos de operação: "conhecimento" e "percepção". 
Em 1961, não há, talvez, nenhum texto ou estudo da Psicopatologia apto a responder adequadamente aos problemas postos por Foucault. Entretanto, no curso do tempo, até a década de 1980, especialmente até 1976 - ano em que, com a publicação de $A$ vontade de saber (La volonté de savoir), o primeiro volume de História da sexualidade (Histoire de la sexualité), percebe-se uma importante inflexão nas ponderações sobre a loucura - , o livro de 1961 não deixa de ser alvo de mal-entendidos e indagações, algumas maliciosas e inoperantes: ${ }^{6}$ por que Foucault, nem psiquiatra nem psicólogo, se interessa pela loucura? Foucault não estaria fantasiando uma história da loucura a partir de dados biográficos, já que não tem contato direto e permanente com o real sofrimento dos loucos internados nos asilos? Foucault responde, em 1975:

Eu pensei em escrever uma história que nunca apareceria, a dos próprios loucos. O que é ser louco? Quem o decide? A partir de quando? Em nome de quê? Esta é uma primeira resposta possível (FOUCAULT, 2006, p. 70).

A despeito do tempo que separa o texto de 1961 das ulteriores investigações genealógicas, História da loucura, precocemente, já anuncia a existência de uma "superfície de contato entre o louco e o poder que se exerce sobre ele" (FOUCAULT, 2006, p. 71): a linguagem da Psiquiatria, um "monólogo da razão", só pode se configurar, pensa Foucault, às custas do silêncio da loucura. "Eu não quis fazer a história dessa linguagem; antes, a arqueologia desse silêncio" (FOUCAULT apud ERIBON, 1990, p. 103).

O livro, uma "arqueologia do silêncio" a que se submete a loucura, estrutura-se, basicamente, a partir de um recorte temporal: Foucault caminha do final da Idade Média e início do Renascimento ao final do século XVIII, empenhado em procurar as condições históricas - e não uma suposta evolução conceitual - que permitem tanto o surgimento da Psiquiatria como discurso científico sobre a loucura quanto a constituição do asilo como lugar de tratamento do louco, no limiar do século XIX.

A observação do Renascimento - fase em que os loucos vivem soltos, errantes, sujeitos à sorte e ao acaso, muitas vezes entregues a um destino supostamente traçados pelos mares ${ }^{7}$ - tem um valor meramente instrumental, mas é decisiva. $\mathrm{O}$ interessante do retorno à Renascença é que Foucault encontra duas formas de consideração da loucura e do louco e o crescente e gradativo predomínio de uma sobre a outra: "experiência trágica” e "consciência crítica". A primeira, expressa na pintura de Bosch, Thierry Bouts, Stephan Lochner, Grünewald, Brueghel, Dürer e, de certa forma, na literatura de Shakespeare e Cervantes, reconhece o fascínio da loucura e o valor do saber próprio do louco, um saber esotérico e profundo, vinculado à "natureza trágica" da existência: o louco é aquele que promete desvelar o mundo, desnudá-lo, pô-lo à prova e à luz, é quem conhece os perigos do universo, os segredos de Satã, o tempo do Apocalipse, a sombria e dolorosa verdade da condição humana, e a loucura, uma "experiência fundamental". Como 
A "secreta fundação" da Psiquiatria: considerações sobre a análise foucaultiana da história da loucura

"experiência trágica", a "loucura tem [...] uma força primitiva de revelação [...]" (FOUCAULT, 1978, p. 27). A segunda, presente no discurso literário e filosófico, identifica loucura à ignorância, ilusão, erro, conduta irregular, e qualifica o louco como "outro da razão". Nos textos de Brant, Erasmo e Montaigne, não mais a alusão ao saber "trágico", mas a referência a uma espécie de "crítica" que admite a loucura como cisão entre o homem e o mundo, exacerbação do individual, ausência de saber. "A loucura só existe em cada homem, porque é o homem que a constitui no apego que ele demonstra por si mesmo e através das ilusões com que se alimenta" (FOUCAULT, 1978, p. 24).

Para Foucault, a "crítica" anunciada por parte da literatura e da filosofia renascentistas, embora incipiente, dá início ao processo de subordinação da loucura pela razão, processo que se radicaliza na era clássica e culmina com a instituição da Psiquiatria no século XIX: não mais pura expressão de um conhecimento "trágico", o saber da loucura é forçado a ceder espaço às exigências do saber racional, porque a razão, aos poucos, vai-se constituindo como a mais legítima morada da verdade e da moralidade. O poder antes atribuído à loucura é, pouco a pouco, confiscado e encoberto pela tirania da razão. Como saber trágico que profere a verdade, a loucura não é propriamente excluída da sociedade renascentista, mas, em face do ideal racionalista de conquista da verdade, a "experiência trágica" é diminuída pela "experiência crítica". Enquanto a Renascença exibe uma certa familiaridade com a "experiência trágica" da loucura, a Idade Clássica transforma a loucura em desrazão negativa. Interessa a Foucault observar que a loucura, desqualificada e inabilitada, aos poucos, perde o poder de exprimir-se pela linguagem: um limite, uma fronteira, um gesto de partilha, um interdito silenciam a loucura. "Mesmo que seja mais sábia que toda ciência, terá de inclinar-se diante da sabedoria para quem ela é loucura" (FOUCAULT, 1978, p. 28). Vivaz, o olhar de Foucault recai sobre este momento de disjunção entre loucura e razão, momento em que, em sua opinião, tem início o "monólogo da razão sobre a loucura".

A Idade Clássica, o tempo em que se consolida o gesto de banimento da loucura da ordem racional, encontra em Descartes seu principal viés filosófico. História da loucura é, deste ponto de vista, um contraponto à filosofia cartesiana que, desde a postulação da "dúvida" e do cogito, ${ }^{8}$ rejeita a loucura e a expulsa para longe do horizonte do pensamento racional: ou loucura ou pensamento. ${ }^{9}$

O exame da era clássica não se atém, prioritariamente, ao nível discursivo: a radicalização do domínio da razão requer a expulsão da loucura inclusive do espaço social. Na era do "Grande Enclausuramento", os insensatos são postos, inicialmente, nos "Hospitais Gerais" criados em toda a Europa; em seguida, a loucura é circunscrita aos muros do "asilo", espaço formado para abrigar exclusivamente os loucos. A loucura não se torna objeto de conhecimento específico nem se caracteriza como doença mental antes de ser objeto de um expurgo, uma excomunhão social.

A análise do lugar da loucura na Idade Clássica se desdobra em dois níveis de investigação: o nível do "conhecimento" e o da "percepção". A distinção entre os dois planos cumpre a função - metodológica - de demonstrar que, na era 
clássica, os critérios de internação do louco não se postulam pela medicina, pelo discurso médico, mas, principalmente, por uma espécie de "percepção social", de "sensibilidade social" (FOUCAULT, 1978, p. 55) e ética difusa, construída por instituições diversas, como a polícia, a justiça, a família e a Igreja. No primeiro nível, Foucault inscreve a medicina classificatória, que não procede à observação dos loucos nem possui qualquer ingerência sobre o internamento, e o direito, que se pronuncia sobre a irresponsabilidade jurídica; no segundo, espaços institucionais, práticas de clausura, fatores sociais, econômicos e políticos. Para compreender o que se passa na Idade Clássica, não é conveniente privilegiar o nível do "conhecimento" médico; é necessário considerar como fundamental o nível "extradiscursivo" ou, como diz Foucault, o "nível da percepção". A diferença da "arqueologia" em relação à "epistemologia" exprime-se, também, na prioridade concedida à "percepção" em detrimento do "conhecimento".

Ilustra a "percepção social" da Idade Clássica a fundação, em 1656, na França, por iniciativa de Luís XIV, do "Hospital Geral", não uma instituição médica, mas uma instituição assistencial, "semi-jurídica" (FOUCAULT, 1978, p. 50) que, localizada no espaço definido entre a polícia e a justiça, isola certos "tipos sociais" perigosos à ordem da sociedade.

\footnotetext{
"Soberania quase absoluta, jurisdição sem apelações, direito de execução contra o qual nada pode prevalecer - o Hospital Geral é um estranho poder que o rei estabelece entre a polícia e a justiça, nos limites da lei: é a terceira ordem da repressão" (FOUCAULT, 1978, p. 50).
}

A articulação entre o nível do "conhecimento" e a esfera das práticas institucionais conduz Foucault à afirmação de que a internação do louco na Era Clássica, revestida de um significado social, econômico, ${ }^{10}$ político e moral, deve ser entendida no contexto das questões referentes à pobreza, à miséria e à mendicância (FOUCAULT, 2006, p. 72). Disseminados por toda a Europa, os "Hospitais Gerais" são, ao mesmo tempo, lugar de reclusão dos ociosos e de assistência aos pobres - "Trata-se de recolher, alojar, alimentar aqueles que se apresentam de espontânea vontade, ou aqueles que para lá são encaminhados pela autoridade real ou judiciária" (FOUCAULT, 2006, p. 49) - , expediente de proteção da sociedade diante do perigo representado pela ociosidade e pela desordem, estratégia de garantia de mão de obra barata e, finalmente, recurso ao desenvolvimento de um projeto político de correção do comportamento, indispensável à administração do Estado. Ao contrário do que ocorre no final da Idade Média e início do Renascimento, na Idade Clássica, a loucura é um problema social que exige medidas eficazes à garantia da ordem social. Contudo, adverte Foucault, a interdição do louco não se justifica por razões exclusivamente econômicas. Sua função primeira é moral, inclusive porque o "trabalho", nessa época, é uma categoria fundamentalmente moral. Para a "percepção social", loucura é desrazão, desordem moral, delírio, linguagem sem nexo. 
Determinam a criação do "Hospital" e a difusão do fenômeno do "Grande Enclausuramento" a necessidade de controle da ociosidade e da imoralidade - em especial, daqueles que adquirem doenças venéreas, das prostitutas e dos sodomitas - , a urgência de domínio do sacrilégio dos magos, blasfemos, feiticeiros e alquimistas, a importância da contenção da ação transgressora dos libertinos e, finalmente, o interesse de controle dos loucos. A finalidade moral do "Grande Enclausuramento" é posta a serviço da esfera política que, por precaução, controla a massa heterogênea para afastar o inconveniente risco da revolta e da insurreição.

Foucault prioriza a "percepção", mas não deixa de apontar a existência de um "conhecimento" médico sobre o louco, ainda que o entenda como um conhecimento médico-jurídico. Apesar da nomeação de um profissional da medicina, a função médica, propriamente dita, não se sobressai no "Hospital Geral", misto de exclusão e assistência, sem "vocação médica". "11 "O século XVIII percebe o louco, mas deduz a loucura" (FOUCAULT, 1978, p. 187), diz Foucault, ciente de que o jeito clássico de lidar com os loucos não resulta da eficácia de métodos terapêuticos ou da competência da palavra científica. Nos séculos XVII e XVIII, a "percepção" social do louco e a medicina são, de fato, duas instâncias descontínuas e separadas, mas não absolutamente. Os dois níveis, em geral, correm paralelos, mas se tocam e se cruzam em alguns momentos já que têm a razão e a moralidade como critério comum a partir do qual instituem a loucura como desrazão. O olhar da Idade Clássica ainda não individualiza o louco nem especifica a loucura como "doença mental". Ao contrário, o louco permanece indistinto no meio da massa heterogênea de indivíduos perigosos e a loucura - a despeito da dificuldade de a medicina compreender a variedade de sintomas do delírio -- é, no máximo, uma doença a ser classificada e incluída no quadro das doenças mais gerais verificadas pela medicina classificatória e taxonômica, inspirada no modelo da história natural.

A partir da segunda metade do século XVIII, ocorrem duas significativas alterações que, afinal, concorrem para a instituição da "doença mental" e da Psiquiatria no século XIX: no nível teórico, a loucura é transformada em "alienação" e, no nível da "percepção" e das práticas, criam-se os asilos, instituições destinadas ao abrigo exclusivo dos loucos.

No nível teórico, forja-se outra tentativa de explicação: a loucura é possível porque a sociedade afasta homem e natureza; afastado da natureza, o homem se perde de si; louco, o homem se afasta da "sua" verdade. Perda da natureza, distanciamento de si, loucura é "alienação". Própria do interior, a loucura vai-se transformando em via de acesso à verdade do homem: "o homo psychologicus é um descendente do homo mente captus", diz Foucault.

No nível da "percepção", a criação do asilo decorre de um duplo movimento de crítica ao "Grande Enclausuramento": se, por um lado, não convém permitir o convívio - instituído por uma decisão arbitrária - entre os indivíduos reclusos e os loucos, por outro, não se pode deixar de absorver a população - entendida agora como fonte de riqueza e força de trabalho - como mão de obra para o capitalismo crescente. Se o louco não deve compartilhar o mesmo espaço com outros tipos sociais nem pode permanecer no seio familiar para receber assistência pri- 
vada, ${ }^{12}$ - tanto a família quanto os recolhidos nas instituições merecem ser protegidos - e se é incapacitado para o trabalho, é necessário mantê-lo aprisionado, é inevitável a configuração de um lugar exclusivo e particular. Perigoso e inapto ao trabalho, o louco é isolado sozinho:

[...] o internamento em casas reservadas estritamente aos loucos começa a ser praticado de modo regular. [...] Esse é um dado quase inteiramente novo em relação ao século XVII. [...] Dir-se-ia uma nova exclusão no interior da antiga, como se tivesse sido necessário esse novo exílio para que a loucura enfim encontrasse sua morada e pudesse ficar em pé sozinha. A loucura encontrou uma pátria que lhe é própria: deslocação pouco perceptível, tanto o novo internamento permanece fiel ao estilo do antigo, mas que indica que alguma coisa de essencial está acontecendo, algo que isola a loucura e começa a torná-la autônoma em relação ao destino com o qual ela estava confusamente misturada (FOUCAULT, 1978, p. 382-384).

O espaço de reclusão é particularizado, a loucura é objetivada, individualiza-se o louco: comportamento, hábitos, alucinações, desvarios e linguagem passam a ser observados, com maior eficácia e mais rigor. A segregação dos loucos em espaços exclusivos não é, portanto, um gesto propriamente médico-científico, mas providência correlata de fatores extracientíficos, expediente tributário de fatores sociais, econômicos e políticos.

$\mathrm{O}$ asilo, o novo lugar destinado à reclusão, diferente do enclausuramento destinado à exclusão e à correção, assume uma dupla função: desvelar a verdade da loucura e, ao mesmo tempo, "eliminá-la" pela cura. Alvo de um olhar minucioso e indiscreto, objeto de conhecimento - porque objeto de observação realizada no interior do asilo - , a loucura agora não implica perda absoluta da razão; antes, representa um conflito interno, subjetivo. No alienado, encontramse vestígios do pensamento racional; pela terapia, pode retornar à mente do louco a razão provisoriamente perdida. De todo modo, a possibilidade da cura exige ainda o descrédito da onipotência da loucura, a desqualificação do poder e do saber da loucura e a alteração da imagem que o louco faz de si próprio. $\mathrm{O}$ asilo, que abre o caminho para a configuração da "doença mental", é dominação ainda mais eficaz da loucura.

Ao contrário do que ocorre no "Hospital Geral", no asilo, a figura do médico é imprescindível. Se o asilo recorre a diversificados procedimentos terapêuticos, é na relação médico-paciente que se pode sustentar a possibilidade da cura, espécie de resultado do antagonismo entre a irracionalidade do louco e a racionalidade do médico. O médico e a terapia são agora os responsáveis pela imputação de sanções aos delírios e devaneios. O espaço do asilo impulsiona o processo de infantilização e culpabilização do louco que, confinado numa espécie de prisão, é, a todo momento, vigiado, julgado e penalizado por suas intenções, desejos e gestos. O médico, "agente das sínteses morais", subordina a cura à assunção dos "sentimentos de dependência, humildade, culpa": curar-se é, em 
parte, reconhecer o próprio erro. Para Foucault, os procedimentos terapêuticos e a relação médico-paciente representam, em última instância, uma relação de poder, encoberta por uma suposta objetividade do conhecimento. "Se a personagem do médico pode delimitar a loucura, não é porque a conhece, é porque a domina [...]" (FOUCAULT, 1978, p. 489).

Não por acaso, Foucault assegura que a criação do asilo concorre para a inauguração da loucura como "doença mental". Das transformações, sobretudo institucionais, advêm as condições históricas de possibilidade de emergência da Psiquiatria: no espaço destinado à reclusão, a loucura torna-se objeto de conhecimento; da perspicácia do olhar atento e da constante vigilância, emerge um conhecimento especial sobre a loucura. A loucura é individualizada como objeto de um saber específico a partir de práticas institucionais; a Psiquiatria do século XIX é resultado do "Grande Enclausuramento", sobretudo do asilo, e não a causa da interdição do louco. ${ }^{13}$ Como ciência que pretende compreender e explicar a loucura, a Psiquiatria não se origina de um olhar humanista: o gesto de Pinel (FOUCAULT, 1978, p. 466-467 e 473-475), um dos mitos da história da Psiquiatria, não se qualifica propriamente como humanitário e libertador. É pela observação das estratégias de controle e dominação que se pode verificar o nascimento do saber psiquiátrico. "Alienado", o louco torna-se "doente mental" e, neste caso, objeto de terapêuticas e práticas de controle muito determinadas.

As lendas de Pinel e Tuke transmitem valores míticos que a psiquiatria do século XIX aceitará como evidências naturais. Mas sob os próprios mitos havia uma operação, ou antes, uma série de operações que silenciosamente organizaram ao mesmo tempo o mundo asilar, os métodos de cura e a experiência concreta da loucura (FOUCAULT, 1978, p. 476).

O texto História da loucura não é escrito no tempo da "genealogia", mas a relação entre o asilo e o processo de patologização da loucura parece antecipar a ideia, cara ao genealogista, de que na base da constituição do saber estão práticas de poder. A constituição da Psiquiatria como discurso teórico sobre o "doente mental" é posterior ao encarceramento do louco. Embora em História da loucura, Foucault ainda opere com uma noção de poder muito próxima da ideia de repressão, compreende-se, em parte, por que, mais tarde, admite a positividadeprodutividade do poder. ${ }^{14}$

Em História da loucura, um livro "bonito como fogos de artifício", Foucault procura mostrar, com a prioridade conferida ao que denomina "percepção", as "fundações secretas", as "origens baixas" da Psiquiatria. A composição da Psiquiatria, no século XIX, deve-se muito mais à reorganização institucional do que propriamente às transformações teóricas, conceituais do discurso médico. Perscrutando as "origens baixas", Foucault se arrisca a dizer que a Psiquiatria dá acabamento ao processo de dominação da loucura - iniciado no Renascimento e radicalizado na Idade Clássica - já que nega à loucura sua linguagem e sua capacidade produtiva de criação e enunciação. 
Não existe linguagem comum; ou melhor, não existe mais; a constituição da loucura em doença mental, no final do século XVIII, atesta um diálogo interrompido, formaliza a separação e lança ao esquecimento todas essas palavras imperfeitas, sem sintaxe fixa, um pouco balbuciantes, nas quais se fazia a comunicação entre loucura e razão (FOUCAULT apud ERIBON, 1990, p. 103).

Se a Psiquiatria extrai da loucura sua capacidade produtiva de criação e enunciação, por isto mesmo, consolida a interdição da linguagem da loucura; a interlocução é negada, rompe-se o diálogo com os loucos: "A ciência das doenças mentais, tal como se desenvolve nos asilos, pertencerá sempre à esfera da observação e da classificação. Não será diálogo" (FOUCAULT, 1978, p. 482).

Compreende-se por que Foucault não poderia ter privilegiado as noções epistemológicas: investigar a loucura a partir da ciência, do registro da história das ciências ou da epistemologia, seria manter a loucura em silêncio e acatar o predomínio da razão, como fazem, em sua opinião, a razão clássica e a Psiquiatria moderna.

No primeiro prefácio escrito para História da loucura, Foucault confessa ter redigido o livro "sob o sol da grande pesquisa nietzschiana". A confissão é clara: para tentar falar da loucura sem silenciá-la, sem dela arrancar o poder de sua linguagem, sem considerá-la "ausência de obra", sem admitir sua palavra como murmúrio "balbuciante", é necessário compreendê-la como uma "experiência trágica" que, mesmo abafada, encoberta, escondida pela "consciência crítica", permanece no interior da cultura ocidental. O poder da crítica racional e moral não é absoluto, diz Foucault, ao analisar o Renascimento: em Sade e em Goya, por exemplo, encontram-se vestígios da "dimensão trágica" da loucura: "Sob a consciência crítica da loucura e suas formas filosóficas ou científicas, morais ou médicas, uma abafada consciência trágica não deixou de ficar em vigília" (FOUCAULT, 1978, p. 29). Nietzsche, Van Gogh, Hölerlin e Artaud são bons testemunhos de que a "experiência trágica" da loucura permanece no interior da cultura ocidental, do século XV ao século XX. A razão crítica silencia a loucura que, como "experiência trágica", teima em se enraizar em discursos resistentes à domesticação e ao interdito, insiste em ressurgir na linguagem transgressora ${ }^{15}$ do pensamento trágico:

[...] obscuramente, essa experiência trágica subsiste nas noites do pensamento e dos sonhos, e aquilo que se teve no século XVI foi não uma destruição radical mas apenas uma ocultação. A experiência trágica e cósmica da loucura viu-se mascarada pelos privilégios exclusivos de uma consciência crítica. É por isso que a experiência clássica, e através dela a experiência moderna da loucura, não pode ser considerada como uma figura total, que finalmente chegaria, por esse 
caminho, à sua verdade positiva; é uma figura fragmentária que, de modo abusivo, se apresenta como exaustiva; é um conjunto desequilibrado por tudo aquilo de que carece, isto é, por tudo aquilo que o oculta. [...] Foi ela que as últimas palavras de Nietzsche e as última visões de Van Gogh despertaram. É sem dúvida ela que Freud, no ponto mais extremo de sua trajetória, começou a pressentir [...] (FOUCAULT, 1978, p. 28-29).

O asilo e a Psiquiatria - e também a Psicanálise - se afastam da "experiência trágica", mas não eliminam a loucura: nas margens, quando o "trágico" é entendido como forma de pensar e dizer - e não no campo da Psiquiatria ou da Psicanálise ${ }^{16}$ - a loucura quebra o silêncio, recupera a palavra e deixa de ser "ausência da obra": só como "experiência trágica" a loucura volta a ser "obra" e pode-se pronunciar sobre o mundo.

Desde o fim do século XVIII, a vida do desatino só se manifesta na fulguração de obras como as de Hölderlin, Nerval, Nietzsche ou Artaud - indefinidamente irredutíveis a essas alienações que curam, resistindo com sua força própria a esse gigantesco aprisionamento moral que se está acostumado a chamar, sem dúvida, por antífrase, de a libertação dos alienados por Pinel e Tuke. (FOUCAULT, 1978, p. 503)

Histoire de la folie ${ }^{17}$ é uma crítica da razão, mais especialmente, dos limites e interditos por ela instituídos para sua própria conservação e para preservação de sua ordem; um olhar oblíquo para uma cultura essencialmente racionalista que, em face do perigo da palavra, outra e maldita, terrível e ameaçadora, interdita e exclui uma parte de si mesma, supostamente estranha e "exterior". Expedientes de recusa, gestos de partilha, estratégias de segregação indicam as "escolhas" de uma sociedade, impõem os "regimes de verdade", desenham o perfil de uma cultura e a identidade dos indivíduos. "A loucura só existe em uma sociedade, ela não existe fora das normas da sensibilidade que a isolam e das formas de repulsa que a excluem ou a capturam" (FOUCAULT, 1999a, p. 150). Ainda que a loucura nunca seja percebida ou alcançada em seu "estado selvagem", "uma coisa permanecerá: a relação dos homens com seus fantasmas, com seu impossível, com sua dor sem corpo, com sua carcaça da noite [...]” (FOUCAULT, 1999b, p. 196). Como sugere Dostoiévski (apud FOUCAULT, 1999c[1961], p. 140), "não é confinando o vizinho que nos convencemos de nosso próprio bom senso."

\section{Notas}

${ }^{1}$ Histoire de la folie à l'âge classique, primeiramente intitulada Folie et désraison, histoire de la folie à l'âge classique (Loucura e desrazão. História da loucura na idade clássica), é a tese de doutorado defendida em 20 de maio de 1961. A tese deveria ter o título L'autre tour de folie ( $A$ outra forma de loucura), inspirado nas palavras de Pascal que aparecem no início do texto. Foi publicada em 1972 pela editora Gallimard e traduzida para o português, em 1978, recebendo o título História da loucura na idade clássica, em uma publicação da editora Perspectiva.

${ }^{2}$ Doença mental e personalidade vem a público em 1954, na "coleção Iniciação filosófica das Presses Universitaires de France, dirigida por Jean Lacroix”. Em 1962, Foucault altera a segunda 
parte do trabalho e dá a ele um novo título: Doença mental e psicologia (Maladie mental et psychologie). Doença mental e psicologia não é considerado por Foucault como seu primeiro livro, estatuto conferido ao texto de História da loucura (Cf. ERIBON, 1990, p. 81; 83).

${ }^{3}$ A banca é composta por Georges Canguilhem, Henri Gouhier e Daniel Lagache. Trinta anos depois, diz Canguilhem (1994, p. 33-36): “[...] se há em meu trabalho universitário um momento com que me sinta feliz, ainda hoje, e de que possa me envaidecer comigo mesmo, foi o de ter sido relator da tese de doutorado de Michel Foucault. [...] para mim, 1961 continua e continuará sendo o ano em que se descobriu um verdadeiro grande filósofo."

${ }^{4}$ Neste ponto, o movimento antipsiquiátrico, iniciado em 1959, se aproxima, em parte, das ponderações de Foucault. Para o movimento, loucura é história e se é história, há que se considerar a importância dos arquivos não revelados pelo discurso racional. Também para Foucault, é preciso reconhecer a dimensão histórica da loucura mediante a observação de práticas socioculturais. No entanto, é necessário lembrar que os objetivos e os procedimentos de Foucault são distintos dos objetivos da antipsiquiatria.

${ }^{5} \mathrm{~A}$ influência da epistemologia é inegável. Em diversas passagens, História da loucura se aproxima da história epistemológica.

${ }^{6}$ Sobre as críticas e os equívocos que se seguem à publicação do livro de Foucault, cf. a importante Introdução de Elisabeth Roudinesco (ROUDINESCO et al., 1994, p. 7-32).

${ }^{7}$ Nas páginas iniciais de História da loucura, Foucault (1978, p. 9), referindo-se a uma prática razoavelmente comum de relação com o louco, afirma: "Um objeto novo acaba de fazer seu aparecimento na paisagem imaginária da Renascença; e nela, logo ocupará um lugar privilegiado: é a Nau dos Loucos, estranho barco que desliza ao longo dos calmos rios da Renânia e dos canais flamengos".

A Narrenschift, símbolo da preocupação renascentista com a loucura, deixa o louco circular pelo mundo, "prisioneiro de sua própria partida", destinado a uma espécie de purificação pela água: "a navegação entrega o homem à incerteza da sorte: [...] todo embarque é, potencialmente, o último. É para o outro mundo que parte o louco, em sua barca louca; é do outro mundo que ele chega quando desembarca. [...] Fechado no navio, de onde não se escapa, o louco é entregue ao rio de mil braços, ao mar de mil caminhos, a essa grande incerteza exterior a tudo. É um prisioneiro no meio da mais livre, da mais aberta das estradas: solidamente acorrentado à infinita encruzilhada. É o Passageiro por excelência, isto é, o prisioneiro da passagem" (FOUCAULT, 1978, p. 12).

${ }^{8}$ "O percurso da dúvida cartesiana parece testemunhar que no século XVII esse perigo está conjurado e que a loucura foi colocada fora do domínio no qual o sujeito detém seus direitos à verdade: domínio este que, para o pensamento clássico, é a própria razão. Doravante, a loucura será exilada. Se o homem pode sempre ser louco, o pensamento, como exercício de soberania de um sujeito que se atribui o dever de perceber o verdadeiro, não pode ser insensato. Traça-se uma linha divisória que logo tornará impossível a experiência, tão familiar à Renascença, de uma Razão irrazoável, de um razoável Desatino. Entre Montaigne e Descartes, algo se passou: algo que diz respeito ao advento de uma ratio" (FOUCAULT, 1978, p. 47-48).

${ }^{9}$ Em Conferência realizada em 1963 e publicada em 1964, "Cogito e história da loucura”, Derrida contesta, veementemente, a interpretação dada por Foucault às Meditações de Descartes, em especial, à postulação cartesiana do cogito e da consequente separação entre loucura e pensamento. Derrida não aceita a relação, estabelecida por Foucault, entre a filosofia de Descartes e o fenômeno do "Grande Enclausuramento". A crítica é incluída na edição do livro de Derrida (1971) A escritura e diferença. Na ocasião, Foucault escreve uma carta a Derrida e, mais tarde, em 1972, responde às críticas de Derrida e inclui sua resposta na reedição de História da loucura. Em sua reposta, Foucault acusa Derrida de distorcer o texto de Descartes e ainda o próprio texto de História da loucura. Em uma outra Conferência, "Fazer justiça a Freud", proferida em 1991, 30 anos após a publicação de História da loucura, Derrida $(1992,1994)$ examina a ambiguidade de Foucault em relação a Freud e, mais uma vez, contesta Foucault.

${ }^{10}$ Aqui, Foucault (2006, p. 72) parece se aproximar, em parte, da análise marxista, como ele próprio admite anos mais tarde, num olhar retrospectivo para a sua primeira grande obra: "[...] o que eu quis fazer em História da loucura foi retomar um problema que era o dos marxistas: a formação de uma ciência no interior de uma sociedade dada".

${ }^{11} \mathrm{Na}$ Conferência "O nascimento do hospital”, diz Foucault (1984c, p. 99-103): "O hospital como instrumento terapêutico é uma invenção relativamente nova, que data do final do século XVIII. 
A consciência de que o hospital pode e deve ser um instrumento destinado a curar aparece claramente em torno de 1780 [...]. O hospital que funcionava na Europa desde a Idade Média não era, de modo algum, um meio de cura, não era concebido para curar. Houve, de fato, na história dos cuidados no Ocidente, duas séries não superpostas; encontravam-se às vezes, mas eram fundamentalmente distintas: as séries médica e hospitalar. O hospital como instituição importante e mesmo essencial para a vida urbana do Ocidente, desde a Idade Média não é uma instituição médica, e a medicina é, nesta época, uma prática não hospitalar. [...] Antes do século XVIII, o hospital era essencialmente uma instituição de assistência aos pobres. Instituição de assistência, como também de separação e exclusão. O pobre como pobre tem necessidade de assistência e, como doente, portador de doença e de possível contágio, é perigoso. Por estas razões, o hospital deve estar presente tanto para recolhê-lo, quanto para proteger os outros do perigo que ele encarna. O personagem ideal do hospital, até o século XVIII, não é o doente que é preciso curar, mas o pobre que está morrendo. [...] O hospital permaneceu com estas características até o começo do século XVIII e o Hospital Geral, lugar de internamento, onde se justapõem e se misturam doentes, loucos, devassos, prostitutas etc., é ainda, em meados do século XVIII, uma espécie de instrumento misto de exclusão, assistência e transformação espiritual, em que a função médica não aparece".

${ }^{12} \mathrm{~A}$ assistência domiciliar é resultante de uma modificação na política de assistência aos pobres.

${ }^{13}$ No texto "A casa dos loucos", diz Foucault (1984d, p. 113-128): “[...] Antes do século XVIII, a loucura não era sistematicamente internada, e era essencialmente considerada como uma forma de erro ou de ilusão. Ainda no começo da idade clássica, a loucura era vista como pertencendo às quimeras do mundo; podia viver no meio delas e só seria separada no caso de tomar formas extremas ou perigosas. [...]".

${ }^{14}$ A consideração da loucura como "experiência trágica" indica dois importantes aspectos ainda presentes em História da loucura: se, em 1961, a loucura é algo fundamental, experiência originária, encoberta, escondida, silenciada, é porque Foucault ainda opera com a ideia de repressão, de poder repressivo. Se a loucura é interditada pela razão, se é sobretudo por ela silenciada, é por que é algo originário reprimido pelo poder. $\mathrm{O}$ próprio Foucault (1984e, p. 7) reconhece: "Quando escrevi História da loucura usei, pelo menos implicitamente, [a] noção de repressão. Acredito que então supunha uma espécie de loucura viva, volúvel e ansiosa que a mecânica do poder tinha conseguido reprimir e reduzir ao silêncio". Só a partir da compreensão de tais aspectos é que se pode, efetivamente, compreender a História da loucura: próximo de Nietzsche, o pressuposto de Foucault é o acolhimento da loucura como "experiência trágica", alternativa à racionalidade. Nas análises genealógicas, a noção de poder repressivo é ultrapassada: "Ora, me parece que a noção de repressão é totalmente inadequada para dar conta do que existe justamente de produtor no poder" (FOUCAULT, 1984e, p. 7-8). A superação da concepção de poder como essencialmente repressivo implica uma significativa alteração no modo de compreender a loucura e sua relação com a razão.

${ }^{15}$ A palavra "transgressão" não está nas linhas de História da loucura. No entanto, como pano de fundo do texto, parece estar presente a relação entre linguagem e as ideias de "limite" e "transgressão", uma clara influência de Blanchot.

${ }^{16}$ Em História da loucura, Foucault mantém uma certa ambiguidade em relação a Freud. Em algumas passagens de História da loucura, Foucault admite que Freud se afasta da psicologia positivista quando reconhece a linguagem do louco, a importância da palavra no processo da cura e, portanto, a possibilidade do diálogo com a loucura. Em outras, no entanto, Foucault aproxima Freud da psiquiatria do século XIX e faz do discurso psicanalítico um herdeiro de Pinel, Tuke e Esquirol. A Psicanálise não proíbe ou interdita a palavra do louco, tal como a Psiquiatria, mas cria um novo tipo de proibição que faz do médico um "taumaturgo". Neste caso, entende que Freud, ao exaltar o papel e a figura do médico na Psicanálise, não recupera totalmente o que ele, Foucault, reconhece como "experiência trágica da loucura". Em face da densidade e da importância do tema, as observações acerca da Psicanálise, de Freud e também de Lacan merecem um estudo mais detalhado e um artigo específico.

${ }^{17}$ Convém lembrar que História da loucura não é a única ou a última palavra de Foucault sobre a loucura, a Psiquiatria, a Psicanálise. No curso da obra, importantes alterações são realizadas em face dos novos objetivos escolhidos. 


\section{REFERÊNCIAS}

CANGUILHEM, G. Abertura. In: ROUDINESCO, E. et. al. Leituras da História da loucura. Rio de Janeiro: Relume-Dumará, 1994. p. 33-36.

DERRIDA, J. A escritura e diferença. Tradução de Maria Beatriz N. da Silva.

São Paulo: Perspectiva, 1971.

DERRIDA, J. Être juste avec Freud; l'histoire de la folie à l'âge de la Psicanálise. In:__. Penser la folie: essais sur Michel Foucault. Paris: Galilée, 1992.

DERRIDA, J. Fazer justiça a Freud: a história da loucura na era da psicanálise. In: . In: ROUDINESCO, E. et al. (Org.). Leituras da História da loucura.

Rio de Janeiro: Relume-Dumará, 1994. p. 53-107.

ERIBON, D. Michel Foucault. São Paulo: Companhia das Letras, 1990.

FOUCAULT, M. Maladie mental et personnalité. Paris: Presses Universitaires de France, 1954.

FOUCAULT, M. Maladie mental et psychologie. Paris: Presses Universitaires de France, 1962.

FOUCAULT, M. Les mots et les choses. Paris: Gallimard, 1966.

FOUCAULT, M. Histoire de la folie à l'âge classique (1961). Paris: Gallimard, 1972.

FOUCAULT, M. Histoire de la sexualité: la volonté de savoir. Gallimard, 1976. coll. TEL. Tome I.

FOUCAULT, M. História da loucura na idade clássica. São Paulo: Perspectiva, 1978.

FOUCAULT, M. Doença mental e Psicologia. Tradução de L. Shalders. Rio de Janeiro: Tempo Brasileiro, 1984a.

FOUCAULT, M. Sobre a prisão. In: MACHADO, R. (Org.). Microfísica do poder. 4. ed. Rio de Janeiro: Graal, 1984b. p. 129-143.

FOUCAULT, M. O nascimento do hospital. In: MACHADO, R.(Org.). Microfísica do poder. 4. ed. Rio de Janeiro: Graal, 1984c. p. 99- 111.

FOUCAULT, M. A casa dos loucos. In: MACHADO, R. (Org.). Microfísica do poder. 4. ed. Rio de Janeiro: Graal, 1984d. p. 113-128. 
A "secreta fundação" da Psiquiatria: considerações sobre a análise foucaultiana da história da loucura

FOUCAULT, M. Verdade e poder. In: MACHADO, R. (Org.). Microfísica do poder. 4. ed. Rio de Janeiro: Graal, 1984e. p. 1-14.

FOUCAULT, M. História da Sexualidade: a vontade de saber. Rio de Janeiro, Graal, 1985. v. 1.

FOUCAULT, M. As palavras e as coisas. 4. ed. Tradução de S. Muchail. São Paulo: Martins Fontes, 1987.

FOUCAULT, M. A loucura só existe em uma sociedade.In:

Problematização do Sujeito: Psicologia, Psiquiatria e Psicanálise. Rio de Janeiro: Forense Universitária, 1999a. Coleção Ditos e Escritos, v. I.

FOUCAULT, M. A loucura, a ausência da obra. In: . Problematização do Sujeito: Psicologia, Psiquiatria e Psicanálise. Rio de Janeiro: Forense Universitária, 1999b. p. 190-198. Coleção Ditos e Escritos, v. I.

FOUCAULT, M. Prefácio (Folie et déraison - 1961). In: Problematização do Sujeito: Psicologia, Psiquiatria e Psicanálise. Rio de Janeiro: Forense Universitária, 1999c. Coleção Ditos e Escritos, v. I.

FOUCAULT, M. Entrevistas. São Paulo: Graal, 2006.

PASCAL, B. Pensamentos. São Paulo: Abril, 1973. Coleção Os Pensadores.

ROUDINESCO, E. Introdução (1961-1986). In: ROUDINESCO, E. et al. (Org.). Leituras da História da loucura. Rio de Janeiro: Relume-Dumará, 1994. p. 7-32.

Recebido em: outubro de 2009

Aceito em: dezembro de 2009 
